\title{
RELIGIOUS AND CULTURAL FEATURES OF CHURCH RECORDS OF CIVIL STATUSPARISH REGISTERS
}

\author{
Anna Hedo \\ Boris Grinchenko Kyiv University \\ Kyiv, Ukraine \\ ORCID: 0000-0003-4151-0747 \\ Olha Kryhina \\ Mariupol State University \\ Mariupol, Ukraine \\ ORCID: 0000-0002-4460-2930
}

\begin{abstract}
This article is an attempt to review religious and cultural features and to find published images on the pages of parish registers of different creeds. To determine and study the relevant and cultural features of the information recording in the parish registers, we considered appropriate to consolidate the comparative and historical-cultural method. The interest of scholars and novelty are proved due to the extremely large information potential of the church reports of civil status, considering their large array in the state archives and satisfactory physical status, suitable for appendage. The study of ecclesiastical acts of civil status makes it possible to study the religious and cultural peculiarities via the records characteristic for representatives of different religions. We should separately mention the peculiarities of the entries in parish registers of the Orthodox population regarding the veneration of holy figures according to the church calendar, which impacted the naming of newborns. Jewish records are characterized by the rite of circumcision of newborn boys and records as for a marriage contract ("ksubba / ktubba").German-language parish registers attract attention to the double names given to newborn babies, the obligation to declare an forthcoming marriage, and the presence of family information in records of the deceased.
\end{abstract}

Keywords: parish registers, church records, ethnic groups, cultural features, religion, birth, marriage, death.

\section{INTRODUCTION}

Relevance of research. Church records of civil status registration contain a vast informational potential and make it possible to identify the features of recording the information about the birth, marriage and death of the represen- 
tatives of different creeds. The novelty of our research and interest of scholars are driven by the extremely high information potential of church civil status records, in view of their large data set in the state archives and satisfactory physical condition suitable for study. Records as for civil status, conducted at the churches, contain information helpful for the study of demographic processes in a particular region, biographies, histories of individual families. The study of assimilation processes, changes in denominations, which are reflected in the parish registers, allows us to study the ethno-confessional history of the population of Ukraine, as well as ethno-cultural features characteristic for each ethno-confessional group.

The aim of the work is to investigate the religious and cultural features typical for representatives of different religions according to the church records of civil status registration. To determine and study the religious and cultural features of the fixation of information in the metric books we combined comparative and historical-cultural methods.

\section{RESEARCH AND INTRODUCTION OF KEEPING RECORDS IN PARISH REGISTERS}

Since the 90s of the twentieth century parish registers have been studied in several directions. The most significant were the studies of Dmitry Antonov and Irina Antonova, who drew attention to the informative potential of the source and codicological features of the parish registers ${ }^{1}$. Sergey Guzenkov studied the peculiarities of recording acts of baptism and burial of the representatives of non-Orthodox Christian denominations ${ }^{2}$. In addition to the use of parish registers information for demographic and genealogical research, increased attention is paid to the study of records as for the representatives of the non-Orthodox religion. The study by Olena Knyazeva ${ }^{3}$ is devoted to the study of the informative potential of the metrics of Lutheran counties. Parish records of the Jewish communities of Galicia became an object of research by Igor Smolsky ${ }^{4}$. Comparative analysis of parish registers among different de-

\footnotetext{
Д. Н. Антонов, И. А. Антонова, Метрические книги России XVIII - начала XX в., Москва 2006.

2 С. Гузенков, Метричні книги як джерело з історичної демографії Південної Украӥни другої половини XIX - початку XX cm.: дис. ... кандидата іст. наук: 07.00.06, Запоріжжя 2005.

3 Е. Е. Князева, Метрические книги Санкт-Петербургского консисториального округа как источник по истории лютеранского населения Российской империи ХVIII нач. $X X$ вв.: дисс. ... кандидата ист. наук: 07.00.09, Санкт-Петербург 2004.

4 I. Смольський, Метричні книги єврейських громад Галичини як джерело до генеалогії, “Генеалогічні записки Українського геральдичного товариства" 2004, вип. IV, с. 77-82.
} 
nominations of Donbass was performed by Olha Vasyk and Anna Gedjo ${ }^{5}$. The scientific literature has established the idea that parish registersin Ukrainian churches were introduced by Peter the Great in 1722 . However, the first metric reforms were initiated by Peter Mohyla, Anthony Vynnytsky, Joseph Shumlyansky and Barlaam Yasinsky in the XVII century. Unfortunately, they did not extend to all Ukrainian lands and had limited influence. Parish registers were introduced slowly due to the reluctance and unwillingness of most priests to follow the instructions of the church authorities. The situation was also influenced by total unpreparedness of the organizational structures of the Orthodox Church to ensure effective control over the course of metric reform ${ }^{6}$. The decree by Peter the Great from April 14, 1702 ordered to register the facts of births and deaths in Russia 7 . In 1724, the Synod developed a detailed form of parish registers, according to which church records were obligatory to consist of three parts - on births, marriages and deaths. An updated form of parish registers with changes and additions was approved in 1838 . The completion of the introduction and improvement of church records was their slow transformation into the registration of changes in civil status.

The analysis of parish registers contained in the funds of the state archives of the Donetsk region as for the representatives of both Orthodox and non-Orthodox population shows that the conduct of church records met the requirements established at the legislative level. The Church records had a typical form and consisted of three parts, except the parish registers of the Jews only, where there was the fourth part about the divorced. Each part of the parish registers reflected the ethnic and cultural features of different religions, despite the fact that the main purpose of the parish registerswas "to know about the number of people born, and in marriage and died in the Russian state" .

\section{FEATURES OF PARISH REGISTERSOF REPRESENTATIVES OF DIFFERENT CREEDS}

The study of the first part of the parish registers on the birth of people of different religions revealed some peculiarities: in particular, parents of the Christian faith were forbidden to leave their children unbaptized and without proper upbringing, as well as for Orthodox parents to baptize their children

\footnotetext{
5 О. Васик (Кригіна), А. Гедьо, Метричні книги греків та євреїв Донбасу: порівняльнотипологічний аспект дослідження, "Нові сторінки історії Донбасу” 2009, кн. 17/18, c. $340-348$.

Н. Лобко, Інформаційний потенціал украӥнських генеалогічних джерел та його використання в історичних дослідженнях: дис. ... кандидата іст. наук: 07.00.06б Київ 2008, c. 7, 69 .
}

7 Полное собрание законов Российской империи, т. 4, № 1908, с. 192.

8 Полное собрание законов Российской империи, т. 7, № 4480, с. 267. 
in any another faith. Orthodox Christians usually baptized their children between the eighth and fortieth day of life. An analysis of the parish registers of the Orthodox population shows that the total number of babies born was baptized a few days after birth. The baptism presupposed the obligatory presence for the recipients (God-parents), information about which was also put down in the parish registers. Baptism was always preceded by naming the baby. In the Orthodox tradition, the names of infants had to be Orthodox, being given in the name of a Saint, information about whom contained in the "Saints" (so called "Svyatsy"). In the column "Names of those born", along with the name given to the baby at baptism, there was also information about the Saint on behalf of who the child was named. Characteristic features could be found in the parish registers on the birth of the German population. In particular, there was no information on infant baptism in the lists of born Mennonites, because according to religious canons, Mennonites did not baptize infants, but only performed water baptism of persons who reached $18-20$ years of age ${ }^{9}$. In course of analysis of the records as for the birth of a child, attention is attracted by the following record: "Baptism out of necessity." For representatives of the Lutheran tradition, such a rite was prescribed by the charter and performed in certain cases: if the baby was born very weak and could die before the arrival of the preacher; if there was no evangelical Lutheran preacher, who could perform the rite of baptism within the period established by law, near the place of the child's birth, as well as in other emergencies. In German (Catholic and Lutheran) parishes, children were given several names: one was personal, other names were given after the names of those present at the baptism. Very often there were relatives among the receivers, there also were frequent cases when the receivers were husband and wife ${ }^{10}$. The detail of keeping a parish registerson birth among the Jewish population was the mandatory indication of the dates of birth of the child and the rite of circumcision of newborn boys, which was held on the 8th day after the birth of the child. There was a difference in the parish registers of the second part - about married people, in particular, it was obligatory for the Orthodox population to conduct a marriage frisk, for the German-speaking population - a triple announcement of marriage, and for Jews it was conclusion of a marriage contract - ksubba / ktubba. The wedding in the Orthodox population was necessarily preceded by a marriage frisk, during which the priest recorded various documentary evidence about the bride and groom. Before the wedding, both of the newlyweds and the witnesses had to confirm with their signature in the Marriage certificate (search)

\footnotetext{
9 С. Д. Бондарь, Секта меннонитов в России (в связи с историей немецкой колонизации на юге России), Петроград 1916.

10 О. Васик (Кригіна), А. Гедьо, Метричні книги греків та євреїв Донбасу: порівняльнотипологічний аспект дослідження..., in the work cited.
} 
that the conclusion of their union is carried out by mutual consent and desire, and not by coercion. The marriage certificate also included the evidence of the brides' mental health, which could be a serious obstacle to marriage. It was forbidden to marry blood relatives ${ }^{11}$. In the Lutheran parish registerswas made on the date of engagement, then there entered information about the announcement and the wedding, for which a separate column was allocated. By charter, each marriage was preceded by an announcement. During three weeks, it was necessary to announce three times in the church (both in the parish of the bride and the groom) the intention to marry, with an exact indication of the names, surnames, titles, position or craft and location of the bride and groom and their parents. After the announcement, a wedding ceremony was held. Representatives of the Evangelical Lutheran Church were also forbidden to enter into marriages between blood relatives. In the Roman Catholic Church, the levels of consanguinity in the lateral lines were different, so sometimes the marriage was concluded with the permission of the bishop. In such cases, the following was written in the parish register: "consist in the third and fourth degree of kinship, received permission from the bishop."The parish registers of married Jews also had their peculiarity, as they contained an indication of the main acts between those who marry and information on witnesses to the event, of who there were usually two. Before marriage, Jews entered into a marriage contract with witnesses. Ksubba was a marriage contract that included general rules: dress a wife, provide for the wife, perform marital duties, provide the wife with a certain amount in the event of a divorce. Analysis of the Jewish parish registers proves that there was no indicated sum for ksubba; the least was 25 , the largest was 500 rubles. The parish registers of the Jewish population are notable for the presence of a separate section that contained information on divorces. With the divorce of Jews both with or without the return of the dowry, the permission of the rabbi or his assistant was required. Records of the Jewish population of the Mariupol city and the district reveal the following reasons for divorce: "On family disagreements between spouses"; "On hostility between spouses"; "On dislike and discord between spouses"; "Due to quarrels and arguments between spouses." The last part of the records about the deceased contained typical information, with a fixed cause of death and age of the deceased. The records of the German-speaking population of the Roman Catholic tradition were different: the record of the deceased contained complete information about his family, indicating their age. Besides it contained surnames of married women ${ }^{12}$. For example: “№ 12; 14.09.1886 in the village of Neyamburg Johann Hoffmann died of a stroke; the settler-owner at

\footnotetext{
11 Ibidem.

12 Державний архів Донецької області, ф. 211, 214, 450, 472, 482, [in:] http://tsdea.archives.gov.ua/ua/metric-books/, access: 12.03.2021.
} 
the age of 53 of the Bergtal Roman Catholic parish, a parishioner, left a wife: Juliana, sons: Lorenza, Johann, Caspar, Henry, Christian, daughters: Christina (by her husband Budyan), Carolina, Helena, Maria, Loisa and Juliana; the body of the Bergtal parish, Joseph Reder, was buried on September 18, 1886, by his teacher, in the local cemetery" ${ }^{\prime 3}$. Such information about the genus facilitates the search for genealogical information and avoids mistakes in the case when many namesakes lived in a village.

\section{CONCLUSIONS}

Thus, the analysis of parish registersof representatives of different religious traditions revealed ethnocultural features characteristic for each group. In particular, the veneration of church saints and giving their names to infants, which is reflected in the records of the Orthodox population; indication of the rite of circumcision and marriage contract, as well as the presence of a separate parish register for records of divorces found in the Jews; double names of infants, the need for three announcements before marriage; the indication of all family members when recording the deceased are characteristic of the metrics of the German-speaking population.

\section{REFERENCES}

Antonov D.N., Antonova I.A. 2006. Metričeskie knigi Rossii XVIII - načala XX v. Moskva: Ros. gos. gumanit. un-t. [Антонов Д.Н., Антонова И.А. 2006. Метрические книги России XVIII - начала XX в. Москва: Рос. гос. гуманит. ун-т].

Bondar' S.D. 1916. Sekta mennonitov v Rossii (v svâzis istoriej nemeckoj kolonizacii na ûge Rossii). Petrograd [Бондарь С.Д. 1916. Секта меннонитов в России (в связи с историей немеикой колонизации на юге России). Петроград].

Deržavnij arhìv Donec'koï oblastì (DADO). F.211,214, 450, 472, 482. http://tsdea.archives.gov.ua/ua/metric-books/ [Державний архів Донецької області (ДАДО). Ф.211, 214, 450, 472, 482. ttp://tsdea.archives.gov.ua/ua/metric-books/].

Guzenkov S.G. 2005. Metrični knigi âk džerelo z istoričnoï demografï Pìvdennoï Ukraïni drugoï polovini $X I X$ - počatku XX st.: dis. ... kandidata ìst. nauk: 07.00.06. Zaporižžâ [Гузенков С.Г. 2005. Метричні книги як джерело з історичної демографії Південної України другої половини XIX-nочатку XX cm.: дис. ... кандидата іст. наук: 07.00.06. Запоріжжя].

Knâzeva E.E. 2004. Metričeskie Knigi Sankt-Peterburgskogo konsistorial'nogo okruga kak istočnik po istorii lûteranskogo naseleniâ Rossijskoj imperii XVIII nač. XX vv.: diss. ... kandidataist. nauk: 07.00.09. Sankt-Peterburg [Князева Е.Е. 2004. Метрические книги Санкт-Петербургского консисториального округа как источник по

13 Державний архів Донецької області, ф. 214, 450, 472, 482, [in:] http://tsdea.archives. gov.ua/ua/metric-books/, access: 12.03.2021. 
истории лютеранского населения Российской империи ХVIII нач. ХХ вв.: дисс. ... кандидата ист. наук: 07.00.09. Санкт-Петербург].

Lobko N.V. 2008. İnformacìnij potencìal ukraïns'kih genealogičnih džerel ta jogo vikoristannâ v ìstoričnih doslìdžennâh: dis. ... kandidata ìst. nauk: 07.00.06. Kï̈v [Лобко Н.В. 2008. Інформаційний потениіал українських генеалогічних джерел та його використання в історичних дослідженнях: дис. ... кандидата іст. наук : 07.00.06. Київ].

Polnoe sobranie zakonov Rossijskoj imperii. Sobranie 1. Т.4. № 1908: 192 [Полное собрание законов Российской империи. Собрание 1. Т.4. № 1908. с. 192].

PSZ-1 T.7. № 4480. S. 266-267. [ПС3-1 T.7. № 4480. C. 266-267]

Smol's'kij İ. 2004. Metrični knigi êvrejs'kih Gromad galičini âk džerelodo genealogiï. “Genealogičnì zapiski Ukraïns'kogo geral'dičnogo tovaristva". Vip. IV: 77-82. [Смольський I. 2004. Метричні книги єврейських громад Галичини як джерело до генеалогії. "Генеалогічні записки Українського геральдичного товариства". Вип. IV: 77-82].

Vasik (Krigìna) O.V. 2009. Metričnì knigi âk džerelo informaciï z istoriï nìmcìv Donbasu. "Vìsnik Čerkas'kogo unìversitetu. Serîa: İstoričnì nauki" Nr 160/161: 54-60 [Васик (Кригіна) О.В. 2009. Метричні книги як джерело інформації з історії німиів Донбасу. “Вісник Черкаського університету. Серія: Історичні науки” № 160/161: 54-60].

Vasik (Krigìna) O.V., Ged'o A.V. 2009. Metričnì knigi grekìv ta êvrë̈v Donbasu: porìvnâl'no-tipologičnij aspekt doslidžennâ. "Novì storìnki ìstoriï Donbasu” Kn. 17/18: 340348 [Васик (Кригіна) О.В., Гедьо А.В. 2009. Метричні книги греків та євреїв Донбасу: порівняльно-типологічний аспект дослідження. "Нові сторінки історії Донбасу” Кн. 17/18: 340-348].

\title{
РЕЛІГІЙНІ ТА КУЛЬТУРНІ ОСОБЛИВОСТІ ЦЕРКОВНИХ АКТІВ ГРОМАДЯНСЬКОГО СТАНУ (МЕТРИЧНІ КНИГИ)
}

\begin{abstract}
Анотація: У статті розглянуті релігійні та культурні особливості представників різних віросповідань за матеріалами метричних книг щодо народжених, одружених та померлих. Для виявлення та дослідження особливостей фіксації інформації у метричних книгах були застосовані порівняльний та історико-культурний методи. Надзвичайно великий інформаційний потенціал метричних книг та їх задовільний стан дають можливість дослідження релігійних та культурних особливостей, які характерні для представників різних віросповідань. Дослідження виявило відмінності щодо фіксації даних серед представників православного населення (шанування святих при наданні імен немовлятам, шлюбний обшук), а також іудеїв (обряд обрізання хлопчиків та шлюбний договір «ксубба-ктубба») та німецькомовного населення (подвійні імена немовлят, оголошення перед укладанням шлюбу).
\end{abstract}

Ключові слова: метричні книги, церковні записи, етнічні групи, культурні особливості, релігія, народження, шлюб, смерть. 


\section{RELIGIJNE I KULTUROWE OSOBLIWOŚCI KOŚCIELNYCH AKTÓW STANU CYWILNEGO (KSIĘGI METRYKALNE)}

Streszczenie: Celem artykułu jest przegląd cech religijnych i kulturowych, które znajdują odzwierciedlenie na stronach ksiąg metrykalnych różnych wyznań. Dla określenia i przebadania religijnych i kulturowych cech informacji w księgach metrykalnych, należy zastosować metody porównawcze i historyczno-kulturowe. Niezwykle duży potencjał informacyjny cerkiewnych akt stanu cywilnego oraz ich zadawalający stan dają możliwość badania religijnych i kulturowych odmienności, charakterystycznych dla przedstawicieli różnych wyznań religijnych. Analiza ujawniła odmienność zapisów informacji pomiędzy społecznościami: prawosławną (kult świętych wyrażający się w wyborze imion nadawanym dzieciom); żydowską (ceremoniał obrzezania niemowląt płci męskiej, kontrakt ślubny - ketuba); niemieckojęzycznej (nadawanie dzieciom podwójnych imion, zapowiedzi przed zawarciem ślubu).

Słowa kluczowe: książki metrykalne, akta cerkiewne, grupy etniczne, cechy kulturowe, wyznanie. 